\title{
4,9-Dihydroxyphenazine-1,6-dicarboxylic Acid Dimethylester and the 'Missing Link' in Phenazine Biosynthesis
}

\author{
By H. KORTH,* A. ROMER, $†$ H. BUDZIKIEWICZ $\dagger$ \\ AND G. PULVERER* \\ *Hygiene-Institut der Universität zu Köln, Goldenfelsstrasse 21, \\ 5000 Köln 41, Federal Republic of Germany \\ and \\ † Institut für Organische Chemie der Universität zu Köln, Greinstrasse 4, \\ 5000 Köln 41, Federal Republic of Germany
}

(Received 27 September 1977)

\begin{abstract}
4,9-Dihydroxyphenazine-1,6-dicarboxylic acid dimethylester, the ester form of a proposed 'missing link' in the biosynthesis of phenazines, has been isolated from a strain of Pseudomonas cepacia.
\end{abstract}

\section{INTRODUCTION}

Morris \& Roberts (1959) isolated a phenazine pigment from a bacterium able to synthesize poly- $\beta$-hydroxybutyric acid, but did not elucidate its structure. Later this pigmentproducing bacterium was classified as Pseudomonas multivorans by Stanier, Palleroni \& Doudoroff (1966), but is now known as Pseudomonas cepacia (Ballard et al., 1970).

From a strain of $P$. multivorans $(=P$. cepacia) we have isolated probably the same pigment and found that its structure seems to be related to that of the proposed 'missing link' in phenazine biosynthesis (Podojil \& Gerber, 1970). During the biosynthesis of the phenazines pyocyanin and iodinin, two molecules of shikimic acid give rise to the phenazine ring (Hollstein \& Marshall, 1972; Flood, Herbert \& Holliman, 1972; Hollstein \& McCamey, 1973; Herbert, Holliman \& Sheridan, 1974, 1976) with the branch point at chorismic acid (Calhoun, Carson \& Jensen, 1972; Longley et al., 1972; Byng \& Turner, 1976). However, the nature of any steps between chorismic acid and the phenazine ring was unknown. We report here the isolation and structural elucidation of a phenazine pigment which fits in with the common precursor hypothesis of Podojil \& Gerber (1970).

\section{METHODS}

Strain. The pigment was isolated from strain ATCC 17460 of $P$. multivorans (Stanier et al., 1966), now named P. cepacia (Ballard et al., 1970); in contrast to the findings of Stanier et al. (1966), it did not utilize saccharose or xylose as sole carbon source.

Medium. The medium, used in solid form, contained $\left(\mathrm{g}^{-1}\right): \mathrm{KH}_{2} \mathrm{PO}_{4}, 4 ; \mathrm{MgSO}_{4} .7 \mathrm{H}_{2} \mathrm{O}, 0 \cdot 5 ;\left(\mathrm{NH}_{4}\right)_{2} \mathrm{SO}_{4}$, 5 ; $\mathrm{FeSO}_{4} .4 \mathrm{H}_{2} \mathrm{O}, 0.05$; glucose, 15; Bacto-agar (Difco), 18; the pH was adjusted to 7.4 with $\mathrm{KOH}$. This medium $(800 \mathrm{ml}$ ) was mixed with $200 \mathrm{ml}$ DST agar (Oxoid) before pouring into plates.

Culture conditions. After inoculation the plates were incubated at $30^{\circ} \mathrm{C}$ for $24 \mathrm{~h}$ and subsequently at room temperature for $3 \mathrm{~d}$.

Isolation of the pigment. Organisms were scraped off plates, suspended in acetone, stirred for $1 \mathrm{~h}$, allowed to stand and then the supernatant was removed by decanting. Treatment with acetone and decantation was repeated twice. The cell material was washed with methanol and stirred for $30 \mathrm{~min}$ with methanol/11.6 M$\mathrm{HCl}(19: 1, \mathrm{v} / \mathrm{v}) ; 1$ vol. chloroform and 4 vol. water were then added. The chloroform phase was concentrated to one-tenth of its original volume and extracted with 2 vol. $3 \mathrm{M}-\mathrm{HCl}$. The aqueous phase was 
Compound $\quad R^{1} \quad R^{2} \quad R^{3} \quad R^{4}$<smiles>[R]c1ccc([R])c2nc3c([R])ccc([R])c3nc12</smiles>

$\begin{array}{rllll}\text { I } & \mathrm{OH} & \mathrm{COOCH}_{3} & \mathrm{COOCH}_{3} & \mathrm{OH} \\ \text { II } & \mathrm{OCH}_{3} & \mathrm{COOCH} & \mathrm{COOCH}_{3} & \mathrm{OCH}_{3} \\ \text { III } & \mathrm{OCH}_{3} & \mathrm{COOH} & \mathrm{COOH} & \mathrm{OCH}_{3} \\ \text { IV } & \mathrm{OCH}_{3} & \mathrm{H} & \mathrm{H} & \mathrm{OCH}_{3} \\ \text { V } & \mathrm{OH} & \mathrm{CH}_{3} & \mathrm{CH}_{3} & \mathrm{OH} \\ \text { VIII } & \mathrm{OCH}_{3} & \mathrm{OCH}_{3} & \mathrm{H} & \mathrm{H} \\ \text { IX } & \mathrm{OH} & \mathrm{OH} & \mathrm{COOCH}_{3} & \mathrm{COOCH}_{3}\end{array}$<smiles>[R]N1c2c(OC)ccc(OC)c2N([R])c2c(C(=O)OC)ccc(OC)c21</smiles>

$\begin{array}{cl}\text { VI } & \mathrm{R}=\mathrm{H} \\ \text { VII } & \mathrm{R}=\mathrm{CH}_{3}\end{array}$<smiles>C=Nc1c(O)ccc(C(=O)OC)c1N=C</smiles>

Structure A

Chemical shift $(\delta)$

8.60 p.p.m.

7.28 p.p.m.

Fig. 1. Chemical structure of the phenazine pigment of Pseudomonas cepacia and related derivatives.

diluted with water (4 vol.) and extracted twice with chloroform. The washed and dried chloroform phase yielded the pigment (I, Fig. 1) after evaporation.

Analytical procedures. Infrared (i.r.) spectra of $\mathrm{KBr}$ discs were recorded using a Perkin-Elmer 720 spectrometer and nuclear magnetic resonance (n.m.r.) spectra were obtained using a Varian EM 390 instrument. A Varian MAT 731 mass spectrometer was used to obtain mass spectra and for precise mass determinations. Melting points could not be determined due to sublimation prior to liquefaction.

\section{Preparation of derivatives of the pigment.}

4,9-Dimethoxyphenazine-1,6-dicarboxylic acid dimethylester (II, Fig. 1). To the pigment (I) dissolved in benzene, an ether solution of diazomethane was added. Evaporation to dryness and sublimation (133 Pa, $200{ }^{\circ} \mathrm{C}$ ) yielded pure II.

4,9-Dihydroxy-1,6-dimethylphenazine (V, Fig. 1). Pigment I was treated for $2 \mathrm{~h}$ with $\mathrm{LiAlH}_{4}$ in boiling tetrahydrofuran then $2 \mathrm{M}-\mathrm{HCl}$ was added, followed by extraction with ether and sublimation (133 Pa, $150^{\circ} \mathrm{C}$ ).

4,9-Dimethoxyphenazine-1,6-dicarboxylic acid (III, Fig. 1). Compound II was treated overnight with $10 \%(\mathrm{w} / \mathrm{v}) \mathrm{NaOH}\left(60^{\circ} \mathrm{C}\right)$, washed twice with chloroform and acidified with $2 \mathrm{M}-\mathrm{HCl}$. The red precipitate was collected and washed with chloroform and methanol.

4,9-Dimethoxyphenazine (1,6-Dimethoxyphenazine) (IV, Fig. 1). Compound III was dissolved in diphenyl ether, mixed with $\mathrm{Cu}$ powder and heated overnight at $250^{\circ} \mathrm{C}$. The mixture was filtered through silica gel. Chromatography on silica gel using petroleum ether eluted the diphenyl ether. Subsequent elution with chloroform yielded IV.

5,10-Dihydro-4,9-dimethoxy-5,10-dimethylphenazine-1,6-dicarboxylic acid dimethylester (VII, Fig. 1). This derivative was obtained by hydrogenation $\left(\mathrm{PtO}_{2}\right)$ of $\mathrm{II}$ in ethanol for $2 \mathrm{~h}$. The dihydro derivative (VI) was dissoved in dimethylformamide and methylated with $\mathrm{NaH} / \mathrm{CH}_{3} \mathrm{I}$. 
Table 1. Summary of data on the pigment $(I)$ and its derivatives

\begin{tabular}{|c|c|c|c|c|c|}
\hline \multirow[b]{2}{*}{ Compound } & \multirow[b]{2}{*}{ Number } & \multicolumn{2}{|c|}{ Precise mass $(m / e)$} & \multirow{2}{*}{$\begin{array}{l}\text { Empirical } \\
\text { formula }\end{array}$} & \multirow{2}{*}{$\begin{array}{l}\text { U.v. absorption } \\
\text { maxima in } \\
\text { methanol (nm) }\end{array}$} \\
\hline & & Found & Calculated & & \\
\hline $\begin{array}{l}\text { 4,9-Dihydroxyphenazine- } \\
\text { 1,6-dicarboxylic acid } \\
\text { dimethylester }\end{array}$ & I & $328 \cdot 0702$ & $328 \cdot 0695$ & $\mathrm{C}_{16} \mathrm{H}_{12} \mathrm{~N}_{2} \mathrm{O}_{6}$ & $450,365,350$ \\
\hline $\begin{array}{l}\text { 4,9-Dimethoxyphenazine- } \\
\text { 1,6-dicarboxylic acid } \\
\text { dimethylester }\end{array}$ & II & $358 \cdot 1166^{*}$ & $358 \cdot 1176$ & $\mathrm{C}_{18} \mathrm{H}_{18} \mathrm{~N}_{2} \mathrm{O}_{6}$ & 430,362 \\
\hline $\begin{array}{l}\text { 4,9-Dimethoxyphenazine- } \\
\text { 1,6-dicarboxylic acid }\end{array}$ & III & $330^{*}$ & & & \\
\hline 1,6-Dimethoxyphenazine & IV & $240 \cdot 0899$ & 240.0898 & $\mathrm{C}_{14} \mathrm{H}_{12} \mathrm{~N}_{2} \mathrm{O}_{2}$ & \\
\hline $\begin{array}{l}\text { 4,9-Dihydroxy- } \\
\text { 1,6-dimethylphenazine }\end{array}$ & V & $240 \cdot 0899$ & 240.0899 & $\mathrm{C}_{14} \mathrm{H}_{12} \mathrm{~N}_{2} \mathrm{O}_{2}$ & \\
\hline $\begin{array}{l}\text { 5,10-Dihydro-4,9-dimethoxy- } \\
\text { 5,10-dimethylphenazine- } \\
\text { 1,6-dicarboxylic acid } \\
\text { dimethylester }\end{array}$ & VII & $386 \cdot 1473$ & $386 \cdot 1477$ & $\mathrm{C}_{20} \mathrm{H}_{22} \mathrm{~N}_{2} \mathrm{O}_{6}$ & \\
\hline
\end{tabular}

Table 2. Features of n.m.r. spectra of the phenazine pigment of Pseudomonas cepacia and its derivatives

Spectra were obtained at $90 \mathrm{MHz}$ using samples dissolved in $\mathrm{CDCl}_{3}$ or, for compound III, $\mathrm{CF}_{3^{-}}$ COOD. Results show chemical shifts ( $\delta$-values, in p.p.m.) and, where appropriate, coupling constants $(j$, in $\mathrm{Hz}$ ) and multiplicity (s, singlet; $\mathrm{m}$, multiplet).

$\begin{array}{cccccccc}\text { Compound } & \mathrm{H}-2,7 & \mathrm{H}-3,8 & \mathrm{H}-4,9 & \mathrm{O}-\mathrm{CH}_{3} & \mathrm{COOCH}_{3} & -\mathrm{CH}_{3} & \mathrm{~N}-\mathrm{CH}_{3} \\ \text { I } & 8.60 & 7.28 & - & - & 4.04 & - & - \\ & j 8.4 & j 8.4 & & & \mathrm{~s} & & \\ \text { II } & 8.58 & 7.14 & - & 4.24 & 4.08 & - & - \\ & j 8.4 & j 8.4 & & \mathrm{~s} & \mathrm{~s} & & \\ \text { III } & 9.45 & 7.93 & - & 4.57 & - & - & - \\ & \mathrm{m} & \mathrm{m} & & \mathrm{s} & & & \\ \text { IV } & 7 \cdot 15 & 7.80 & 8.08 & 4 \cdot 20 & - & - & - \\ & j 7.5 ; 1.5 & j 8.0 ; 7.5 & j 9.0 ; 1.5 & \mathrm{~s} & & & \\ \text { V } & 7.63 & 7.02 & - & - & - & 2.83 & - \\ & j 8.4 & j 8.4 & & & & \mathrm{~s} & \\ \text { VII } & 8.50 & 7.30 & - & 4.27 & 4.05 & - & 2.77 \\ & j 8.4 & j 8.4 & & \mathrm{~s} & \mathrm{~s} & & \text { broad s }\end{array}$

RESULTS

The pigment (I) was extracted from harvested organisms as described in Methods. The properties of various derivatives prepared from it are summarized in Table 1, and features of their n.m.r. spectra are shown in Table 2. Figure 1:shows the basic chemical structure of the isolated pigment together with eight theoretically possible derivatives (II to IX).

The elemental composition of the isolated pigment, $\mathrm{C}_{16} \mathrm{H}_{12} \mathrm{~N}_{2} \mathrm{O}_{6}$, was determined by exact mass measurement. $\mathrm{D}_{2} \mathrm{O}$ exchange proved the presence of two acidic protons. Infrared absorption at 3300 to $3500 \mathrm{~cm}^{-1}$ and formation of a dimethyl ether (vide infra) showed that these protons belonged to two hydroxyl groups. The remaining four oxygen atoms were accounted for by two aromatic carbomethoxyl groups (i.r., strong absorptions at $1715 \mathrm{~cm}^{-1}$; n.m.r., singlet at $\delta=4.04$ p.p.m., $6 \mathrm{H}$, disappearing after reduction with $\mathrm{LiAlH}_{4}$ ). The remaining four hydrogen atoms were aromatic ones (n.m.r., two doublets at $\delta=8.60$ and 7.28 p.p.m.), the coupling constant $(j=8.4 \mathrm{~Hz})$ showing them to be ortho to each other. The large difference in chemical shift $(\Delta \delta=1.32$ p.p.m.) could be explained only by opposing substituent effects (Pretsch et al., 1976) (de-shielding by the $\mathrm{COOCH}_{3}$, and 
shielding by the $\mathrm{OH}$ function). Correspondingly, in the dimethyl derivative (V) the lowfield protons were found at $\delta=7.63$ p.p.m. All these data were consistent with the partial structure A (Fig. 1). The shielding effect involving para-H in phenol is only of minor importance in phenazinols (cf. IV, and Sigg \& Toth, 1967; Weigele \& Leimgruber, 1967) supporting the identification of the proton giving a signal at $\delta=7 \cdot 28$ p.p.m. as ortho to the hydroxyl group. Analogous arrangement of the substituents and identical spectral behaviour have been reported for lomofungin (1-carbomethoxy-5-formyl-4,6,8-trihydroxyphenazine; Tipton, Kenneth \& Rinehart, 1970). The observation of the coincidence of all n.m.r. signals by pairs with reference to partial structure A was compatible both with structure I ( $C_{2 h}$ symmetry) and structure IX ( $C_{2 v}$ symmetry). It was possible to distinguish between these because the pigment could be degraded to 1,6-dimethoxyphenazine (IV) which was identical with an authentic sample (thin-layer chromatography, mass spectrometry, n.m.r., i.r.). Further evidence for structure I has been provided by the $N, N$-dimethyl$N, N$-dihydro derivative, VII (obtained by hydrogenation and methylation). The n.m.r. spectrum of this derivative exhibited only one $N$-methyl signal (slightly broadened by the quadrupole moment of nitrogen) while for the analogous product from IX two signals would have been expected. The pigment isolated from $P$. cepacia was thus shown to be the same as compound I (partial structure A).

\section{DISCUSSION}

4,9-Dihydroxyphenazine-1,6-dicarboxylic acid was suggested by Podojil \& Gerber (1970) to be an intermediate in the biosynthesis of phenazines. Byng \& Turner $(1976,1977)$ presented evidence that, in Pseudomonas phenazinium, phenazine-1,6-dicarboxylic acid acts as a branch point compound for the biosynthesis of 1,6-dihydroxyphenazine (and iodinin) and for phenazine-1-carboxylic acid and related compounds. This would explain why all naturally occurring phenazines possess $\mathrm{C}$-substituents only on $\mathrm{C}_{1}$ or $\mathrm{C}_{1}$ and $\mathrm{C}_{6}$ (Tipton et al., 1970; Nakamura, Maeda \& Umezawa, 1964; Nakamura et al., 1959; Aguilar-Santos, 1970; Gerber, 1969; Olson \& Richards, 1967). The intermediates between chorismic acid and phenazine-1,6-dicarboxylic acid are not known. Byng \& Turner (1976) suppose that the number of steps between chorismic acid and 'the hypothetical key intermediate common to all natural phenazines' may be large. It may well be that 4,9-dihydroxyphenazine-1,6dicarboxylic acid dimethylester is one of these intermediates. Hollstein, Krisov \& Mock (1976) reported that phenazine-1,6-dicarboxylic acid dimethylester is metabolized by Pseudomonas aureofaciens. We have found that a mutant of a strain of $P$. aureofaciens excretes in addition to phenazine-1-carboxylic acid, 2-hydroxyphenazine-1-carboxylic acid and 2-hydroxyphenazine-1,6-dicarboxylic acid (strain 13cR, unpublished observation).

In preliminary experiments with $P$. aureofaciens, degradation of the pigment to phenazine1,6-dicarboxylic acid or phenazine-1-carboxylic acid was not observed. A possible explanation is that the molecule did not penetrate the cell wall (Byng \& Turner, 1976).

We thank Professor E. Breitmaier, University of Bonn, for a sample of compound IV and the Deutsche Forschungsgemeinschaft for the mass spectrometer.

\section{REFERENCES}

AguilaR-Santos, G. (1970). Caulerpin, a new red pigment from green algae of the genus Caulerpa. Journal of the Chemical Society $(C), 842-843$.

Ballard, R. W., Palleroni, N. J., Doudoroff, M., STANIER, R. Y. \& MANDEL, M. (1970). Taxonomy of the aerobic pseudomonads: Pseudomonas cepacia, $P$. marginata, $P$. alliicola and $P$. cariophylli. Journal of General Microbiology 60, 199214.
Budzikiewicz, H. (1970). Die Abhängigkeit der Massenspektren organischer Verbindungen von instrumentellen Parametern. Croatica chemica acta 42, 567-581.

Byng, G. S. \& TuRner, J. M. (1976). Isolation of pigmentation mutants of Pseudomonas phenazinium. Journal of General Microbiology 97, 57-62.

BYNG, G. S. \& TURNER, J. M. (1977). Incorporation of $\left.{ }^{14} \mathrm{C}\right]$ shikimate into phenazines and further 
metabolism by Pseudomonas phenazinium. Biochemical Journal 164, 139-145.

Calhoun, D. H., Carson, M. \& Jensen, R. A. (1972). The branch point metabolite for pyocyanine biosynthesis in Pseudomonas aeruginosa. Journal of General Microbiology 72, 581-583.

Flood, M. E., Herbert, R. B. \& Holliman, F. G. (1972). Pigments of Pseudomonas species. Part V. Biosynthesis of pyocyanin and the pigments of $P S$. aureofaciens. Journal of the Chemical Society, Perkin I, 622-626.

GERBER, N. N. (1969). New microbial phenazines (1). Journal of Heterocyclic Chemistry 9, 297-300. Herbert, R. B., Holliman, F. G., \& Sheridan, J. B. (1974). Biosynthesis of iodinin: incorporation of $\mathrm{D}-\left[1-{ }^{14} \mathrm{C}\right]-, \mathrm{D}-\left[6-{ }^{14} \mathrm{C}\right]-$ and $\mathrm{D}-\left[1,6,7-{ }^{14} \mathrm{C}_{3}\right]$ shikimic acid. Tetrahedron Letters, 4201-4204.

Herbert, R. B., Holliman, F. G. \& Sheridan, J. B. (1976). Biosynthesis of microbial phenazines: incorporation of shikimic acid. Tetrahedron Letters, 639-642.

Hollstein, U. \& Marshall, L. G. (1972). Biosynthesis of phenazines. Journal of Organic Chemistry 37, 3510-3514.

Hollstein, U. \& MCCAMEy, D. A. (1973). Biosynthesis of phenazines. II. Incorporation of $\left[6-{ }^{14} \mathrm{C}\right]$-D-shikimic acid into phenazine-1-carboxylic acid and iodinin. Journal of Organic Chemistry 38, 3415-3417.

Hollstein, U., KRISOv, G. E. \& Mock, D. L. (1976). Biosynthesis of phenazines - the role of phenazine1,6-dicarboxylic acid. Tetrahedron Letters, 32673270.

Longley, R. P., Halliwell, J. E., Campbell, J. J. R. \& INGLEDEW, W. M. (1972). The branch point of phenazine biosynthesis. Canadian Journal of Microbiology 18, 1357-1363.
Morris, M. B. \& RoberTs, J. B. (1959). A group of pseudomonads able to synthesize poly- $\beta$-hydroxybutyric acid. Nature, London 183, 1538-1539.

Nakamura, S., Lin Wang, E., Murase, M., Maeda, K. \& UMEzAWA, H. (1959). Structure of Griseolutein A. Journal of Antibiotics, Tokyo, Series A 12, 55-58.

Nakamura, S., Maeda, K. \& UmezaWa, H. (1964). Structure of Griseolutein B. Journal of Antibiotics, Tokyo, Series A 17, 33-36.

Olson, E. S. \& Richards, J. H. (1967). The structure of the orange pigment from Pseudomonas aureofaciens. Journal of Organic Chemistry 32, 28872890.

PodoJIL, M. \& Gerber, N. N. (1970). Biosynthesis of 1,6-phenazinediol 5,10-dioxide (iodinin). Incorporation of shikimic acid. Biochemistry 9, 4616-4618.

Pretsch, E., Clerc, I., Seibl, J. \& Simon, W. (1976). Tabellen zur Strukturaufklärung organischer Verbindungen mit spektroskopischen Methoden. Berlin, Heidelberg and New York: Springer-Verlag.

SigG, H. P. \& TotH, A. (1976). Úber die Struktur der Phenazin- $N$-Oxide. Helvetica chimica acta $\mathbf{5 0}$, 716-719.

Stanier, R. Y., Palleroni, N. J. \& Doudoroff, M. (1966). The aerobic pseudomonads: a taxonomic study. Journal of General Microbiology 43, 159-271.

Tipton, C. D., KenNeTh, L. \& RinehaRT, K. L. (1970). Lomofungin. Degradative studies of a new phenazine antibiotic. Journal of the American Chemical Society 92, 1425-1426.

WEIGELE, M. \& LeIMGRUBER, W. (1967). The structure of myxin. Tetrahedron Letters, 715-718. 